\title{
Serologic survey of West Nile virus in horses from Central-West, Northeast and Southeast Brazil
}

\author{
Jaqueline Raymondi Silva', Larissa Campos de Medeiros², Vinícius Pinho dos Reis', \\ Juliana Helena Chávez ${ }^{1}$, Thiago Demarchi Munhoz ${ }^{3}$, Gustavo Puia Borges ${ }^{4}$, \\ Otavio Augusto Brioschi Soares ${ }^{7}$, Carlos Henrique Coelho de $\mathrm{Campos}^{7}$, \\ Rosângela Zacarias Machado ${ }^{3}$, Cristiane Divan Baldani ${ }^{3}$, Maria Luana Cristiny Rodrigues Silva ${ }^{5}$, \\ Joice Lara Maia Faria ${ }^{6}$, Edson Elias da Silva², Luiz Tadeu Moraes Figueiredo ${ }^{1 /+}$
}

\footnotetext{
${ }^{1}$ Centro de Pesquisa em Virologia, Faculdade de Medicina de Ribeirão Preto, Universidade de São Paulo, Ribeirão Preto, SP, Brasil

${ }^{2}$ Departamento de Virologia, Instituto Oswaldo Cruz-Fiocruz, Rio de Janeiro, RJ, Brasil ${ }^{3}$ Faculdade de Ciências Veterinárias, Universidade Júlio de Mesquita Filho, Jaboticabal, SP, Brasil ${ }^{4}$ Escola de Ciências Veterinárias, Universidade Federal do Mato Grosso do Sul, Campo Grande, MS, Brasil ${ }^{5}$ Universidade Federal de Campina Grande, Campina Grande, PB, Brasil ${ }^{6}$ Universidade de Uberaba, Uberaba, MG, Brasil ${ }^{7}$ Academia Militar Agulhas Negras, Resende, RJ, Brasil
}

Since the emergence of West Nile virus (WNV) in North America in 1999, there have been several reports of WNV activity in Central and South American countries. To detect WNV in Brazil, we performed a serological survey of horses from different regions of Brazil using recombinant peptides from domain III of WNV. Positive samples were validated with the neutralisation test. Our results showed that of 79 ELISA-positive horses, nine expressed WNVspecific neutralising antibodies. Eight of the infected horses were from the state of Mato Grosso do Sul and one was from the state of Paraiba. Our results provide additional evidence for the emergence of WNV in Brazil and for its circulation in multiple regions of the country.

Key words: West Nile virus - Flavivirus - Brazil

West Nile virus (WNV), a member of the genus Flavivirus, is responsible for large outbreaks of disease in the Old World as well as in the New World (i.e., in North America) (Kilpatrick 2011). Since its emergence in New York City during an encephalitis outbreak in 1999, WNV has infected millions of humans and horses in North America (Petersen \& Hayes 2008). Since its initial emergence, WNV activity has been reported in Central and South America, with specific antibodies detected in birds and horses (Komar \& Clark 2006). In 2006, WNV was isolated from the brains of two dead horses in Argentina (Morales et al. 2006). In Brazil, WNV-specific neutralising antibodies were reported for the first time in horses from Nhecolândia, which is in the Pantanal region of the state of Mato Grosso do Sul (Pauvolid-Corrêa et al. 2011). Recently, serological evidence of WNV activity in horses and chickens has also been reported in the Brazilian Pantanal (Melandri et al. 2012). To date, the Brazilian health authorities have not reported any cases of WNV infection in humans or horses. Here, we report the results of a serological survey for WNV in different regions of Brazil.

Geographic locations of horse sera sample collection - Between 2004-2009, serum samples were collected from 753 horses from the states of São Paulo

doi: $10.1590 / 0074-0276130052$

Financial support: FAPESP-2008/50167-6

+ Corresponding author: 1tmfigue@fmrp.usp.br

Received 27 January 2013

Accepted 29 April 2013
(SP) $(\mathrm{n}=183)$, Minas Gerais $(\mathrm{n}=15)$ and Rio de Janeiro $(\mathrm{RJ})(\mathrm{n}=200)$ in Southeast Brazil, from the state of Paraíba (PB) $(\mathrm{n}=88)$ in Northeast Brazil and from MS $(n=267)$ in Central-West Brazil. All participating horses were healthy at the time of blood collection and had no history of central nervous system infection or Flavivirus vaccination. Furthermore, the horses enrolled in this study had not travelled to areas in which WNV had been reported previously. A blood sample was collected from each animal by jugular venipuncture using vacutainers. Serum was separated by centrifugation and kept at $-20^{\circ} \mathrm{C}$ until use. The sample collection and handling procedures were approved by the Animal Ethical Committee of the University of São Paulo (USP).

Screening of horse sera by ELISA - Domain III of the flavivirus envelope protein is known to contain the critical antigenic epitopes that react with neutralising antibodies during Flavivirus infection. Therefore, we generated recombinant antigens consisting of domain III (rDIII) of WNV, Saint Louis encephalitis virus (SLEV) and Rocio virus (ROCV) in Escherichia coli (Chavez et al. 2010). An rDIII-ELISA was conducted according to a protocol previously standardised at the Virology Research Centre, School of Medicine of Ribeirão Preto, USP (Chavez et al. 2013). All sera were tested by rDIII ELISAs specific for SLEV, ROCV and WNV. Samples were considered positive at a dilution of 1:100 based on a cut-off point calculation.

Neutralisation test (NT) - Serum samples that tested positive in the WNV rDIII-ELISA, but not in the SLEV or ROCV ELISAs, were subsequently subjected to a NT, as previously described (Hawkes 1979). WNV 
strain NY-99 (kindly supplied by Dr Barbara W Johnson from the Centers for Disease Control and Prevention Fort Collins, CO, USA) was used in this assay. End-point titres were determined as the highest dilution of serum capable of neutralising $100 \%$ of a viral suspension at $100 \mathrm{TCID}_{50}$.

Serum samples from 79 horses (10.5\%) tested positive for WNV by rDIII-ELISA. Of these, only nine (11.3\%) neutralised WNV, with reciprocal neutralising titres ranging from 16-128 in the NT (Table). Eight of these samples were isolated in MS and one was from $\mathrm{PB}$ (Figure). All other serum samples that tested positive in the WNV rDIII-ELISA, including those from animals of the southeastern states of SP $(n=19)$ and RJ $(n=34)$, tested negative in the NT.

It is possible that many of the sera samples tested positive in ELISA as a result of assay cross-reactivity with other flaviviruses; these animals could have been infected by multiple flaviviruses during their lifetimes. In light of this, we considered only the serum samples that reacted in both the rDIII-WNV ELISA and WNVNT as positives. Our results corroborate a report from 2011 showing that WNV-neutralising antibodies were found in 3\% of the horses sampled in MS (Pauvolid-Corrêa et al. 2011). Recently, WNV-neutralising antibodies were found in horses and chickens sampled in the state of Mato Grosso (Melandri et al. 2012). It is possible that WNV was introduced, most likely by migratory birds, to the wildlife of the Pantanal region, which is a sanctuary for flora and fauna. It is well established that birds from North and South American countries migrate to certain Brazilian regions, including the Pantanal, each winter. Due to the large diversity of flora and fauna, as well as the high density of mosquitoes found in the Pantanal, this region may support the establishment and spread of WNV into other regions of the country (Pauvolid-Corrêa et al. 2011).

Between 2006-2008, serological studies in Central and South American countries reported WNV seroconversion in horses, humans and other vertebrates (Pe- tersen \& Hayes 2008). Interestingly, all of the WNVpositive horses in the present study were sampled in 2009 , suggesting that they were likely infected prior to 2008. The spread of WNV between Central and South American countries likely contributed to the emergence of this virus in Brazil. It is possible that WNV has infected horses and/or humans in this region. However, to date, there have been no reports of human or horse diseases attributed to WNV in Brazil. Together, our results suggest that WNV is circulating and infecting horses in the Central-West Region of Brazil. The single positive sample from PB seems to be the first serological evidence of WNV circulation in Brazil outside of

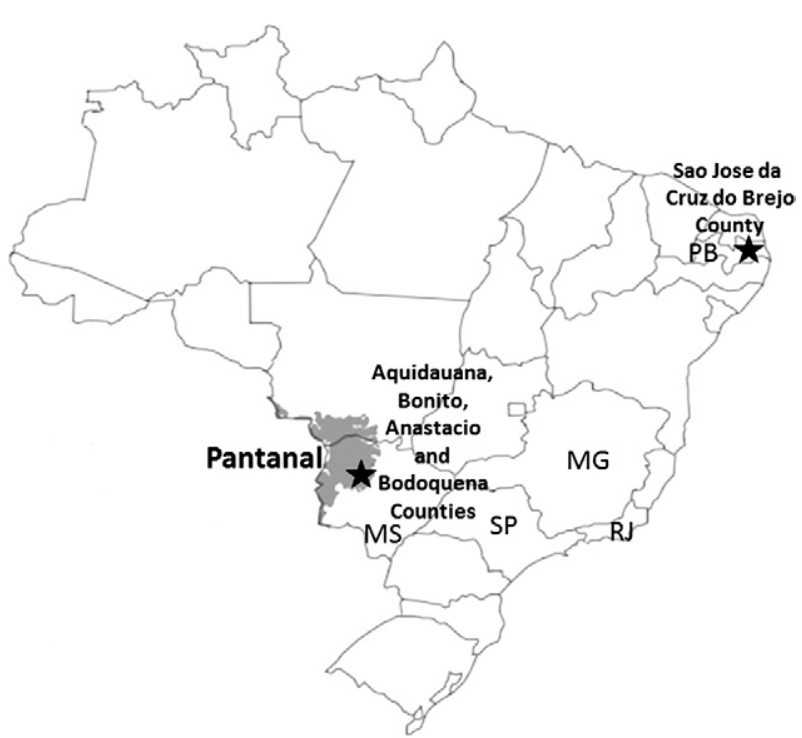

Map of Brazil showing the locations where horses were sampled, including Pantanal region and cities, and the state of Paraíba (PB) where seropositive horses to West Nile virus were found. MG: state of Minas Gerais; MS: state of Mato Grosso; RJ: state of Rio de Janeiro; SP: state of São Paulo.

TABLE

Positive samples to West Nile (WNV) virus in rDIII-WNV ELISA, their respective states and cities and neutralisation test (NT) titres

\begin{tabular}{lcccc}
\hline Sample & Sampling date & State & City & NT titre \\
\hline 2 & 17 Jan 2009 & MS & Aquidauana & 16 \\
23 & 17 Jan 2009 & MS & Aquidauana & 32 \\
25 & 19 Jan 2009 & MS & Aquidauana & 64 \\
34 & 27 Jan 2009 & MS & Aquidauana & 128 \\
35 & 27 Jan 2009 & MS & Bonito & 32 \\
21 & 8 Jan 2009 & MS & Anastácio & 32 \\
26 & 19 Jan 2009 & MS & Bodoquena & 32 \\
28 & 4 Feb 2009 & MS & São José da Cruz do Brejo & 32 \\
76 & 7 Jul 2009 & PB & \\
\hline
\end{tabular}

MS: state of Mato Grosso do Sul; PB: state of Paraíba. 
Pantanal and suggests that WNV is spreading toward the northeastern regions of the country. Health authorities should intensify surveillance for WNV in humans, horses and birds to evaluate the extent of the spread and to avoid the undetected emergence of WNV as a public health problem in Brazil.

\section{REFERENCES}

Chavez JH, Reis VP, Silva JR, Laure HJ, Rosa JC, Fonseca BAL, Figueiredo LTM 2013. Production and diagnostic application of recombinant domain III of West Nile envelope protein in Brazil. Rev Soc Bras Med Trop 46: 97-99.

Chavez JH, Silva JR, Amarilla AA, Figueiredo LTM 2010. Domain III peptides from flavivirus envelope protein are useful antigens for serologic diagnosis and targets for immunization. Biologicals 38: 613-618

Hawkes R 1979. General principles underlying laboratory diagnosis of viral infections. In E Lennete, Diagnostic procedures for viral, rickettsial and chlamydial infections. American Public Health Association, Baltimore, p. 3-48.
Kilpatrick AM 2011. Globalization, land use and the invasion of West Nile virus. Science 334: 323-327.

Komar N, Clark GG 2006. West Nile virus activity in Latin America and the Caribbean. Rev Panam Salud Publica 19: 112-117.

Melandri V, Guimarães AE, Komar N, Nogueira ML, Mondini A, Fernandez-Sesma A, Alencar J, Bosch I 2012. Serological detection of West Nile virus in horses and chicken from Pantanal, Brazil. Mem Inst Oswaldo Cruz 107: 1073-1075.

Morales MA, Barrandeguy M, Fabbri C, Garcia JB, Vissani A, Trono K, Gutierrez G, Pigretti S, Menchaca H, Garrido N, Taylor N, Fernandez F, Levis S, Enria D 2006. West Nile virus isolation from equines in Argentina, 2006. Emerg Infect Dis 12: 1559-1561.

Pauvolid-Corrêa A, Morales MA, Levis S, Figueiredo LTM, CoutoLima D, Campos Z, Nogueira MF, da Silva EE, Nogueira RMR, Schatzmayr HG 2011. Neutralising antibodies for West Nile virus in horses from Brazilian Pantanal. Mem Inst Oswaldo Cruz 106: 467-474.

Petersen LR, Hayes EB 2008. West Nile virus in the Americas. Med Clin North Am 92: 1307-1322. 